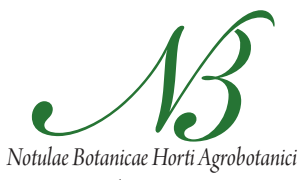

Cluj-Napoca

\title{
Path Analysis of Yield and Quality Traits in Alfalfa
}

\author{
Hassan MONIRIFAR \\ East Azarbaijan Research Center for Agriculture and Natural Resources, Agronomy and \\ PlantBreeding Department, Tabriz, Iran; monirifar@yahoo.com
}

\begin{abstract}
An investigation was carried out using 13 alfalfa accessions during 2009 to 2010 and was located on the experimental field of East Azarbaijan Agriculture and Natural Resources Research Center (AZARAN), Iran. The objective of this research was to evaluate positive effect and reliability of yield and quality traits as selection criteria in alfalfa breeding. Significant differences were observed for most of the yield and quality components. Variability coefficients were high for yield components, while quality traits showed relatively low variation. Plant height (PH), number of stems (NS), number of nodes (NN) and leaf size (LS) was positively correlated with plant yield. Crude protein (CP) content was correlated directly with acid detergent fiber (ADF) and natural detergent fiber (NDF) while correlation with crude fiber $(\mathrm{CF})$ was inverse. The direct effect of the number of stems on yield had the highest value $(0.698, \mathrm{P}<0.01)$. Direct effect of number of nodes on yield was positive $(0.508, \mathrm{P}<0.01)$. Only the plant height had a lower direct than the indirect effect on yield. The direct effects of independent traits on $\mathrm{CP}$ were significant $(\mathrm{P}<0.05)$, except for trait leaf dry weight $(\mathrm{LDW})$. The direct effect of ADF had the highest value $(2.440, \mathrm{P}<0.01)$, which was positive and significant. $\mathrm{LDW}$ trait had a negative direct effect on the $\mathrm{CP}(-0.248, \mathrm{P}<0.05)$, while the indirect effect on the NDF trait on $\mathrm{CP}$ was neither high nor justifiable. ADF, CF, NDF and LDW traits had the highest indirect effects on $\mathrm{CP}$ trait via correlation with in vitro dry matter digestibility (IVDMD).
\end{abstract}

Keywords:alfalfa, quality, path coefficients, yield

\section{Introduction}

The main objectives of the most alfalfa breeding programs are yield increase and quality improvement. Since it is not possible to achieve genetic progress over the limits determined by existing genes in a population, the choice of germplasm included in a breeding program is a top priority for every breeder (Popovic et al., 2006). As an essential part of each breeding program, the germplasm is primarily based on selection from the existing cultivars and ecotypes (Prosperi et al., 1999). Results obtained by many researches proved the value of local populations as a starting source in alfalfa breeding programs aimed at creating cultivars of a broad genetic base (Popovic et al., 2006; Prosperi et al., 1999; Tavoletti et al., 1999).

Increasing variability of selection material could be achieved by introducing distinct alfalfa varieties, as new source of diversity. Agro-morphological traits have been used to classify and study of genetic diversity in alfalfa germplasm collections as well as other crops (Radovic et al., 2006). Yield and quality are quantitative traits whose expression is influenced by genetic, biological, environmental factors as well as their interactions (Popovic et al., 2006). Alfalfa yield is the result of yield components effect:number of plants per area, number of stems per plant, weight and height of individual stem (Fick et al., 1988), while alfalfa quality is a complex trait determined by morphological, chemical and physiological composition (Kirilov, 2001). Morphological composition in- cludes leaf-to-stem ratio, number and length of internodes (Kirilov, 2001; Rotili et al., 2001).

Selection for improved forage quality has been successful for increasing protein concentration and in vitro dry matter digestibility (IVDMD), and decreasing NDF and acid detergent lignin (ADL) concentration of alfalfa herbage (Coors et al., 1986; Hill, 1981; Hill and Barnes, 1977; Shenk and Elliott, 1971). However, because these selection studies were done on whole herbage, the observed shifts in forage quality may have resulted from inadvertent selection for altered leaf-to-stem ratio. Quality of alfalfa leaf and stem material are sufficiently different that any shifts in relative proportions of leaf and stem results in significant changes in herbage quality (Sheaffer $e t$ al., 2000). In the case of selection for reduced ADL concentration in alfalfa herbage (Hill, 1981), it was shown that the resulting divergence in herbage ADL concentration was due primarily to a higher leaf proportion in the low lignin alfalfa line, although the ADL concentration of stem material did show some response (Kephart et al., 1989, 1990). While a higher leaf-to-stem ratio of the low lignin lines did result in reduced NDF concentration, the increase in IVDMD was minimal and only correlated with NDF concentration (Kephart et al., 1990).

When breeding alfalfa with higher forage quality, other plant characteristics inadvertently can be altered. Correlations between forage quality, and morphological and agronomic traits have been reported (Hill, 1981; Johnson et al. 1994; Kephart et al., 1989; Shenk and Elliot, 
1971; Sumberg et al., 1983). Positive correlations were reported for IVDMD with leaf/stem ratio and number of vascular bundles (Shenk and Elliot, 1971). Negative correlations were reported for lignin with leaf/stem ratio and stem height (Kephart et al., 1989, 1990). Johnson et al. (1994) found positive correlations for CP with leaf/stem ratio and lodging, and negative correlations for $\mathrm{CP}$ and regrowth height. Moderate or no associations have been reported for yield with NDF, ADF, lignin, IVDMD, and CP (Coors et al., 1986; Gil et al. 1967; Hill and Barnes, 1977; Hill, 1981; Kephart et al., 1989; Shenk and Elliot, 1971; Sumberg et al., 1983).

Selection of promising genotypes in a breeding program is based on various criteria, most importantly final crop yield and its quality. Relationships between yield and yield contributing traits also play an important role (Diz et al., 1994; Guler et al., 2001; Mohammadi et al., 2003; Rabiei et al., 2004). Selection may also be based on other plant and/or crop features, such as, early maturity (Ahmad et al., 1991), industrial crop yield (e.g. oil yield, Baye and Becker, 2005), crop resistance (e.g. Bridge, 2000; Singh et al., 2004) and yield quality features (e.g. Gravois, 1998). Whatever criteria are used, there is always a final trait (e.g. yield) or several final traits (e.g. seed yield and quality) to which the most attention is paid. To detect traits having an influence on a final trait, path analysis is commonly applied (Kozak and Kang, 2006; Popovic et al., 2006; Shipley, 2002). The path coefficient analysis provides information on internal relation among the investigated characteristics, as well as their effect on certain trait. The path coefficient is a standardized partial regression coefficient that measures the direct influence of one trait upon another and permits the separation of a correlation coefficient into components of direct and indirect effects (Board et al., 1997). The traits influencing yield and quality may directly or indirectly affect each other and for the purpose of breeding programs, they should be subject to separate analysis. The objective of this research was to evaluate the reliability of most frequently used selection criteria in alfalfa breeding by using variability analysis, phenotypic correlation and path analysis.

\section{Materials and methods}

Thirteen alfalfa ecotypes ('Leghlan', 'Sivan', 'Sattelou', 'Gara-Baba', 'Baftan', 'Ilan-Jough', 'Khaje', 'Dizaj-Safarali', 'Khosrovanagh', 'Alhord', 'Gara-Yonjeh') and 'Ranger' and 'Moapa' control cultivars used as experimental materials. The seeds of ecotypes were planted in individual pots containing a mixture of sandy-loam soil, peat and sand with 2:1:1 ratio on March 2009. From each ecotype, 96 plants were transplanted into the field at the Tikmadash $(75 \mathrm{~km}$ east of Tabriz) in the East Azarbaijan Agriculture and Natural Research Center in the spring of 2009. In each plot, 24 plants were transplanted in 4-row plot 6 plants in each row) $0.6 \mathrm{~m}$ apart and $2.4 \mathrm{~m}$ long.
The trial was established in a randomized complete block design with four replications. The field trial was conducted under irrigated condition for two years where first year was considered for uniformity. All data were recorded from the two central rows on plant height $(\mathrm{PH}$, $\mathrm{cm}$ ), number of shoots (NS), plant fresh weight (PFW, $\mathrm{g} /$ plant) plant dry weight (PDW, g/plant), leaf size (LS, $\mathrm{cm} \times \mathrm{cm}$ ), number of nodes (NN), leaf dry weight (LDW, $\mathrm{g} /$ plant), leaf fresh and dry weight to stem fresh and dry weight, (LFW/SFW) and (LDW/SDW) ratios in the second year. PFW was obtained by hand cutting of plants at approximately $5 \mathrm{~cm}$ above the ground and weighting by electronic balance. To determine PDW, fresh samples of randomly chosen plants were taken from each plot and placed in paper bags. The samples were then weighted and dried at $105^{\circ} \mathrm{C}$ for $24 \mathrm{~h}$ to assess average dry matter content $(\mathrm{DMC})$. PDW were calculated by $\mathrm{DMC} \times$ PFW/100 formula. Total yearly mean PFW and PDW for each plant were determined from each cut and NS of individual plants was recorded directly following cuts. Prior to the cuts, PH was measured from the ground to the top of the inflorescence. The mean of PH, NS, (LFW/SFW) and (LDW/SDW), and the sum of PFW and PDW for each year were used for analysis. Data for in vitro dry matter digestibility (IVDMD\%), crude protein (CP\%), acid detergent fiber (ADF\%), neutral detergent fiber (NDF\%) and crude fiber (CF\%) were predicted using near-infrared reflectance spectroscopy (NIRS) model 8620.

The obtained results were illustrated per plant $(\mathrm{g}, \mathrm{cm}$, $\mathrm{cm} \times \mathrm{cm}, \%)$ in average cutting. Analysis of variance was calculated using PROC GLM (SAS Institute, 1998) to detect significant $(\mathrm{P} \leq 0.05)$ differences between ecotypes. Ecotypes means were separated using Duncan's multiple range test $(P \leq 0.01)$. Simple correlation and stepwise multiple regression analysis' were carried out using SAS statistical program. In addition, the relative importance of direct and indirect effects on yield and crude protein (CP) content was determined by path analysis. In path analysis, yield and crude protein (CP) content were the dependent variables and the four and five characteristics were considered as independent variables respectively.

\section{Results and discussion}

Significant differences were observed between alfalfa ecotypes for plant height $(\mathrm{PH})$, number of nodes (NN), leaf size (LS), number of stems (NS), leaf fresh and dry weight to stem fresh and dry weight ratios (LFW/SFW) and (LDW/SDW), except plant fresh and dry weight (Tab. 1). Smith and Hamel (2005) believed that alfalfa forage yield depends upon three factors including plant number per unit area, stem number per plant and singlestem yield. But Sengul (2002) considered the plant height, stem number per plant and single-stem yield as the forage yield components. These traits are the most frequently used selection criteria in alfalfa breeding programs (Pop- 
192

ovic, 2006). Tuckak et al. (2008) reported that plant height is an important yield component and it is often used as a criterion when choosing superior genotypes in an early stage of selection. The results of this research are consistent with the results of other researchers (Julier $e t$ al., 2000; Popovic, 2006).

In general, coefficient of variation shows the degree of difference and power of trait variation. The results showed a wide range of values of broad variability among traits under study by testing ecotypes. Plant fresh and dry weight had the highest variation coefficient (14.41 and 14.01\%) while the average weight per plants in all cuttings varied from 275.45 to $452.70 \mathrm{gm}$ (Tab. 2).

Among yield components, leaf size and number of stems per plant had the highest relative variability (12.89 and $10.9 \%$, respectively) while plant height trait had a relatively low variability coefficient $(7.71 \%)$. Statistically significant differences were observed between ecotypes for IVDMD, ADF, Ash, CF, NDF and LDW (Tab. 1). Average protein content per plants ranged from $21.31 \%$ to $25.35 \%$ (Tab. 2). Quality traits had a relatively low variation coefficient. IVDMD had the lowest coefficient of variation $(3.76 \%$ ) while the $\mathrm{CP}$ content had $8.31 \%$ coefficient of variation. Tavoletti et al. (1999) obtained similar results in trait variation.

Forage yield and its quality is complex traits whose expression in influenced by genetic constitution of a plant as well as environmental factors, as stated by Julier $e t a l$. (2000). Because of the above-mentioned reasons, determining the genetic potential of the alfalfa ecotypes and the interrelation among traits, are of high importance.

Tab. 3 illustrated the evaluation of direction and correlation among traits tested in this research. The results of correlation analysis showed that plant dry weight had a positive relation with all other yield components. PDW was positively correlated with number of stems $\left(0.876^{* *}\right)$ and plant height $\left(0.612^{* *}\right)$ and leaf size $\left(0.339^{* *}\right)$. Quality traits differed with respect to correlation with yield (Tab. 4). The most important quality trait was crude protein $(\mathrm{CP})$ content and was negatively correlated with $\mathrm{CF}$ $\left(-0.718^{* *}\right)$ but positively correlated with ADF and LDW.

Direct linear relationships among traits were also established (Tab. 3). The relationship between yield and yield components indicate that selection for number of stems may increase yield.

The residual effect of path coefficient for yield trait was 0.54 (Tab. 3). The direct effect of the number of stems on yield had the highest value $\left(0.698^{* *}\right)$ and the ratio of the direct effect of number stems on yield was $79.6 \%$, i.e. about $80 \%$ of the variation in yield comes from the direct effect of the number of stems. Direct effect of number of nodes on yield was positive and statistically significant $\left(0.508^{* *}\right)$, and its ratio was $64.1 \%$. Only the plant height had a lower direct than the indirect effect on yield. Plant height had the highest indirect effect on yield and, in particular, via the number of stems (0.346).
Johnson et al. (1994) pointed out that understanding the relationships between quality and agronomic traits may assist breeding programs. The same authors found significant positive correlation between $\mathrm{L} / \mathrm{S}$ ratio and crude protein content (0.25-0.46), plant height and cellulose content $(0.18-0.72)$ and plant height and green mass yield, maturity, stem diameter and lodging. They also found a significant negative correlation between $\mathrm{L} / \mathrm{S}$ ratio and cellulose content (-0.47 to -0.76$)$.

Evaluating trait variability is a necessary indicator of reliability of certain traits as a criterion for selection but, at the same time, it indicates a possibility of achieving satisfactory progress with these criteria. Smith and Hamel (2005) believe that alfalfa forage yield depends upon three factors including plant number/unit area, stem number/ plant and single-stem yield. However, Sengul (2002) considered the plant height, stem number/plant and singlestem yield as the forage yield components.

Based on the obtained results, it can be noticed that in two-years of research, the number of stems are the most reliable and most reliable selection criterion due to relatively good variability, which makes it a successful criterion in selection for alfalfa yield increase. This fact can be supported by the results obtained by Katepa-Mupondwa et al. (2002) who increased yields by $38 \%$.

The most significant indicators of alfalfa quality are CP and CF (Rotili et al., 2001). The relative variability of traits, which affect quality, was low-from $6.28 \%$ to $11.70 \%$ - considering the fact that alfalfa is an allogamous autotetraploid.

Direct selection of the traits determining quality, as for instance, protein content, will not bring about satisfactory progress, however, the progress can be achieved by indirect improvement of quality trait as pointed out by and Popovic (2006).

The direct effects of independent traits on $\mathrm{CP}$ were significant, except for trait LDW (Tab. 4). The direct effect of ADF had the highest value $\left(2.440^{* *}\right)$, which was positive and significant. The ratio of the direct effect of ADF on CP was very considerable (53.87\%). LDW trait had a negative direct effect on the CP $\left(-0.242^{*}\right)$ which was $17.1 \%$, while the indirect effect on the NDF trait on CP was neither high nor justifiable. ADF, CF, NDF and LDW traits had the highest indirect effects on CP trait via correlation with IVDMD. Residual effect for $\mathrm{CP}$ investigated trait was 0.51 .

Johnson et al. (1994) found positive correlations for $\mathrm{CP}$ with leaf/stem ratio and lodging, and negative correlations for $\mathrm{CP}$ and regrowth height. Moderate or no associations have been reported for yield with NDF, ADF, lignin, IVDMD, and CP (Coors et al., 1986; Hill, 1981; Kephart et al., 1989; Sumberg et al., 1983).

The correlation between quality traits show that indirect selection for protein content increase (CP\%) via IVDMD and ADF traits could be successful while, at the same time, there is a decrease of negative effect of other 
Tab. 1. Analysis of variance for the morphological and qualitative traits of alfalfa ecotypes

\begin{tabular}{|c|c|c|c|c|c|c|c|c|c|c|c|c|c|c|c|}
\hline \multirow{2}{*}{$\begin{array}{l}\text { Source of } \\
\text { variation }\end{array}$} & \multirow{2}{*}{$\mathrm{df}$} & \multicolumn{14}{|c|}{ Means of squares $\dagger$} \\
\hline & & $\mathrm{PH}$ & NS & $\mathrm{NN}$ & LS & PFW & PDW & (LFW/SFW) & (LDW/SDW) & IVDMD & $\mathrm{CP}$ & $\mathrm{ADF}$ & $\mathrm{CF}$ & NDF & LDW \\
\hline Replication & 3 & $137.14^{\mathrm{ns}}$ & $0.36^{\mathrm{ns}}$ & $0.97^{\mathrm{ns}}$ & $0.029^{\mathrm{ns}}$ & $7.10^{\mathrm{ns}}$ & $2.17^{\mathrm{ns}}$ & $0.001^{\mathrm{ns}}$ & $0.002^{\mathrm{ns}}$ & $0.33^{\text {ns }}$ & $6.16^{\mathrm{ns}}$ & $0.57^{\mathrm{ns}}$ & $7.51^{\mathrm{ns}}$ & $8.18^{\mathrm{ns}}$ & $38.53^{\text {ns }}$ \\
\hline Ecotype & 12 & $156.63^{* *}$ & $1.84^{* *}$ & $3.23^{* *}$ & $0.049^{* *}$ & $11.61^{\mathrm{ns}}$ & $11.61^{\mathrm{ns}}$ & $0.003^{*}$ & $0.004^{*}$ & $11.24^{* *}$ & $7.61^{\mathrm{ns}}$ & $14.67^{* *}$ & $17.48^{* *}$ & $25.68^{* *}$ & $149.8^{* *}$ \\
\hline Error & 36 & 44 & 0.53 & 0.97 & 0.012 & 7.66 & 7.65 & 0.001 & 0.002 & 3.33 & 3.88 & 3.11 & 3.87 & 7.52 & 45.91 \\
\hline C.V. & & 7.71 & 10.90 & 7.71 & 12.89 & 14.41 & 14.01 & 8.00 & 10.46 & 3.76 & 8.31 & 4.19 & 6.89 & 5.14 & 6.71 \\
\hline
\end{tabular}

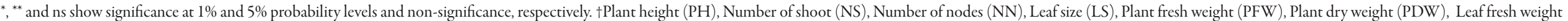

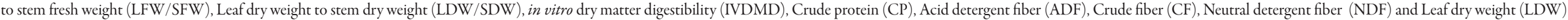

Tab. 2. Mean values of investigated agronomic and qualitative traits $\dagger$ of alfalfa ecotypes

\begin{tabular}{|c|c|c|c|c|c|c|c|c|c|c|c|c|c|c|}
\hline Ecotype & $\mathrm{PH}$ & NS & $\mathrm{NN}$ & LS & PFW & PDW & (LFW/SFW) & (LDW/SDW) & IVDMD & $\mathrm{CP}$ & $\mathrm{ADF}$ & CF & NDF & LDW \\
\hline 'Ilan-Jough' & $85.50 \mathrm{abcd}$ & $48.33 b c$ & $15.00 \mathrm{ab}$ & $0.55 \mathrm{abc}$ & 402.63 & 112.06 & $0.47 \mathrm{bc}$ & $0.38 \mathrm{ab}$ & $47.27 \mathrm{ab}$ & 23.63 & $43.97 \mathrm{a}$ & $29.62 \mathrm{abcd}$ & $54.52 \mathrm{ab}$ & $43.73 \mathrm{ab}$ \\
\hline 'Sivan' & $76.25 \mathrm{~cd}$ & $38.50 \mathrm{~cd}$ & $12.50 \mathrm{c}$ & $0.97 \mathrm{ab}$ & 281.67 & 74.22 & $0.50 \mathrm{abc}$ & $0.47 \mathrm{ab}$ & $47.82 \mathrm{ab}$ & 25.15 & $43.29 \mathrm{ab}$ & $25.96 \mathrm{~d}$ & $55.84 \mathrm{ab}$ & $35.48 \mathrm{bc}$ \\
\hline 'Gara-Yonjeh' & $89.32 \mathrm{abc}$ & $37.25 \mathrm{~cd}$ & $13.75 b c$ & $0.67 \mathrm{abc}$ & 306.08 & 82.13 & $0.49 \mathrm{abc}$ & $0.43 \mathrm{ab}$ & $45.42 \mathrm{~b}$ & 23.01 & $44.70 \mathrm{a}$ & $29.70 \mathrm{abcd}$ & $53.32 \mathrm{ab}$ & $34.43 b c$ \\
\hline 'Dizaj-Safarali' & $89.60 \mathrm{abc}$ & $45.75 \mathrm{bcd}$ & $14.00 \mathrm{abc}$ & $0.86 a b c$ & 400.17 & 109.48 & $0.46 b c$ & $0.41 \mathrm{ab}$ & $47.38 \mathrm{ab}$ & 25.35 & $43.95 a$ & $27.35 \mathrm{~cd}$ & $55.43 \mathrm{ab}$ & $45.11 \mathrm{ab}$ \\
\hline 'Baftan’ & $90.83 \mathrm{abc}$ & $48.50 \mathrm{bc}$ & $13.75 b c$ & $0.97 \mathrm{ab}$ & 419.08 & 115.03 & $0.47 a b c$ & $0.39 \mathrm{ab}$ & $50.67 \mathrm{a}$ & 22.65 & $39.55 \mathrm{bcd}$ & $30.36 \mathrm{abc}$ & $50.79 b c$ & $45.03 \mathrm{ab}$ \\
\hline 'Sattelou' & $91.05 \mathrm{ab}$ & $41.00 \mathrm{~cd}$ & $13.75 b c$ & $0.67 \mathrm{abc}$ & 339.06 & 93.73 & $0.49 \mathrm{abc}$ & $0.41 \mathrm{ab}$ & $48.13 \mathrm{ab}$ & 24.72 & $42.77 \mathrm{abc}$ & $27.70 \mathrm{bcd}$ & $54.21 \mathrm{ab}$ & $39.36 \mathrm{bc}$ \\
\hline 'Gara-Baba' & 87.46abcd & $55.00 \mathrm{a}$ & $13.33 \mathrm{bc}$ & $0.73 \mathrm{abc}$ & 476.27 & 114.95 & $0.49 \mathrm{abc}$ & $0.43 \mathrm{ab}$ & $49.34 a$ & 24.89 & 42.06abcd & $27.90 \mathrm{~cd}$ & $54.31 \mathrm{ab}$ & $49.95 \mathrm{a}$ \\
\hline 'Khosrovanagh' & $82.75 \mathrm{abcd}$ & $43.25 \mathrm{~cd}$ & $12.75 \mathrm{c}$ & $0.88 \mathrm{abc}$ & 372.02 & 94.60 & $0.48 \mathrm{abc}$ & $0.44 a b$ & $49.58 \mathrm{a}$ & 24.40 & 41.26abcd & $26.23 \mathrm{~cd}$ & $53.64 a b$ & $40.92 \mathrm{bc}$ \\
\hline 'Khaje' & $85.00 \mathrm{abcd}$ & $47.00 \mathrm{bc}$ & $13.75 b c$ & $1.0050 \mathrm{a}$ & 443.99 & 118.62 & $0.45 b c$ & $0.41 \mathrm{ab}$ & $50.53 a$ & 21.85 & $38.83 \mathrm{~d}$ & $26.10 \mathrm{~cd}$ & $47.03 c$ & $47.37 \mathrm{a}$ \\
\hline 'Leghlan' & $91.50 \mathrm{ab}$ & $40.50 \mathrm{~cd}$ & $13.75 b c$ & $1.0125 \mathrm{a}$ & 386.75 & 102.71 & $0.44 \mathrm{c}$ & $0.37 \mathrm{~b}$ & $47.88 \mathrm{ab}$ & 23.38 & 42.34abcd & 29.14abcd & $54.77 \mathrm{ab}$ & $37.71 b c$ \\
\hline 'Alhord' & $96.00 \mathrm{a}$ & $51.25 \mathrm{ab}$ & $14.25 a b c$ & $0.74 a b c$ & 452.70 & 120.58 & $0.44 \mathrm{c}$ & $0.38 \mathrm{ab}$ & $48.19 \mathrm{ab}$ & 24.28 & $42.92 \mathrm{abc}$ & 28.33abcd & $53.63 \mathrm{ab}$ & $46.83 \mathrm{ab}$ \\
\hline 'Ranger' & $81.00 \mathrm{bcd}$ & $40.00 \mathrm{~cd}$ & $13.50 b c$ & $0.45 c$ & 275.40 & 72.82 & $0.52 \mathrm{ab}$ & $0.44 a b$ & $50.66 a$ & 22.37 & $39.25 \mathrm{~cd}$ & $32.48 \mathrm{a}$ & $52.49 \mathrm{abc}$ & $32.82 \mathrm{c}$ \\
\hline 'Moapa' & $74.50 \mathrm{~d}$ & $37.00 \mathrm{~d}$ & $16.00 \mathrm{a}$ & $0.50 \mathrm{bc}$ & 344.92 & 88.51 & $0.54 a$ & $0.47 a$ & $46.82 \mathrm{ab}$ & 21.31 & $43.02 \mathrm{abc}$ & $31.71 \mathrm{ab}$ & $57.43 a$ & $42.26 b c$ \\
\hline Total Mean & 86.938 & 44.26 & 13.76 & 0.80 & 380.08 & 101.05 & 0.47 & 0.41 & 48.41 & 23.74 & 42.20 & 28.35 & 53.50 & 41.76 \\
\hline
\end{tabular}

Means with the same letter(s) in each column are not significant at 1\% level. † Plant height (PH), Number of shoots (NS), Number of nodes (NN), Leafsize (LS), Plant fresh weight (PFW), Plant dry weight (PDW), Leaf fresh weight to stem fresh

weight (LFW/SFW), Leaf dry weight to stem dry weight (LDW/SDW), in vitro dry matter digestibility (IVDMD), Crude protein (CP), Acid detergent fiber (ADF), Crude fiber (CF) and Neutral detergent fiber (NDF) 
Tab. 3. Phenotypic path coefficient of yield and its components

\begin{tabular}{|c|c|c|c|c|c|c|c|c|c|c|c|}
\hline \multirow{3}{*}{ Variablet } & \multirow{3}{*}{$\begin{array}{l}\text { Correlation } \\
\text { Coefficients }\end{array}$} & \multirow{2}{*}{\multicolumn{2}{|c|}{ Direct effect }} & \multicolumn{8}{|c|}{ Indirect effect } \\
\hline & & & & \multicolumn{2}{|c|}{$\mathrm{PH}$} & \multicolumn{2}{|c|}{ NS } & \multicolumn{2}{|c|}{ NN } & \multicolumn{2}{|c|}{ LS } \\
\hline & & $\mathrm{p} \neq$ & $\%$ & $\mathrm{p}$ & $\%$ & $\mathrm{p}$ & $\%$ & $\mathrm{p}$ & $\%$ & $\mathrm{p}$ & $\%$ \\
\hline $\mathrm{PH}$ & $0.612^{* *}$ & $0.190^{* *}$ & 27.6 & -- & -- & 0.346 & 50.4 & -0.036 & 5.3 & 0.112 & 16.5 \\
\hline NS & $0.876^{* *}$ & $0.698^{* *}$ & 78.8 & 0.094 & 10.5 & -- & -- & 0.019 & 2.2 & 0.075 & 5.5 \\
\hline $\mathrm{NN}$ & $0.303^{* *}$ & $0.508^{* *}$ & 64.1 & 0.013 & 1.6 & 0.027 & 3.4 & -- & -- & -0.245 & 30.9 \\
\hline LS & $0.339^{* *}$ & $0.451^{* *}$ & 50.6 & 0.047 & 5.3 & 0.117 & 13.1 & -0.276 & 31.0 & -- & -- \\
\hline \multicolumn{12}{|c|}{ Residual effect 0.54} \\
\hline
\end{tabular}

† Plant height (PH), Number of shoot (NS), Number of nodes (NN), Leaf size (LS). ‡p, path coefficient

Tab. 4. Phenotypic path coefficient of crude protein (CP) content

\begin{tabular}{|c|c|c|c|c|c|c|c|c|c|c|c|c|c|}
\hline \multirow{3}{*}{ Variablet } & \multirow{3}{*}{$\begin{array}{l}\text { Correlation } \\
\text { Coefficients }\end{array}$} & \multirow{2}{*}{\multicolumn{2}{|c|}{ Direct effect }} & \multicolumn{10}{|c|}{ Indirect effect } \\
\hline & & & & \multicolumn{2}{|c|}{ IVDMD } & \multicolumn{2}{|c|}{$\mathrm{ADF}$} & \multicolumn{2}{|c|}{$\mathrm{CF}$} & \multicolumn{2}{|c|}{ NDF } & \multicolumn{2}{|c|}{ LDW } \\
\hline & & $\mathrm{p} \neq$ & $\%$ & $\mathrm{p}$ & $\%$ & $\mathrm{p}$ & $\%$ & $\mathrm{p}$ & $\%$ & $\mathrm{p}$ & $\%$ & $\mathrm{p}$ & $\%$ \\
\hline IVDMD & 0.121 & $2.150^{* *}$ & 45.36 & -- & -- & -2.25 & 47.48 & 0.123 & 2.58 & 0.158 & 3.32 & -0.06 & 1.26 \\
\hline $\mathrm{ADF}$ & 0.450 & $2.440^{* *}$ & 53.87 & -1.99 & 43.94 & -- & -- & -0.052 & 1.09 & 0.016 & 0.29 & 0.036 & 0.81 \\
\hline $\mathrm{CF}$ & -0.718 & $-0.348^{* *}$ & 22.8 & -0.763 & 50.5 & 0.370 & 24.3 & -- & -- & -0.009 & 0.47 & 0.032 & 1.90 \\
\hline NDF & 0.383 & $-0.028 \mathrm{~ns}$ & 0.9 & -1.121 & 43.5 & 1.42 & 50.9 & -0.123 & 4.4 & -- & -- & 0.078 & 0.30 \\
\hline LDW & 0.106 & $-0.248^{*}$ & 17.1 & 0.520 & 35.8 & -0.361 & 24.9 & -0.315 & 21.7 & 0.008 & 0.50 & -- & -- \\
\hline & & & & & Residu & effect 0 & & & & & & & \\
\hline
\end{tabular}

$\dagger$ In vitro dry matter digestibility (IVDMD), Acid detergent fiber (ADF), Crude fiber (CF), Neutral detergent fiber (NDF) and Leaf dry weight (LDW).

$\neq$ p, path coefficient

traits that are in a negative relationship with IVDMD and ADF.

Direct effect obtained in path- coefficient analysis indicates that alfalfa plant yield mainly depends on number of stems, which is supported by the results of a similar research conducted by Annicchiarico (2006). The result of path-coefficient analysis for protein content (CP) shows that negative selection should be performed on CF trait, which has strong negative direct and indirect effect via IVDMD trait on CP criterion. Popovic (2006) obtained the same results. For that reason, IVDMD trait is an important component in quality improvement.

Lemaire et al. (1994) concluded that crude protein and fiber content were not directly affected by plant phenological development but protein content was directly related to the dynamic of the dry matter accumulation.

Path analysis showed relatively high values of residual effect indicating that there are other traits not recorded in the research, which may significantly be involved. The values of residual effect were approximately the same as those reported by Popovic (2006).

In conclusion, the result of this investigation indicated that number of stems and acid detergent fiber could be considered as critical criteria's for alfalfa yield and quality improvement respectively.

\section{Acknowledgements}

The research was carried out in the framework of the project "3-35-0305-87052" funded by Iranian Ministry of Jahade Agriculture, AREEO (Agricultural Research, Edu- cation and Extension Organization), SPII (Seed and Plant Improvement Institute).

\section{References}

Ahmad Q, Rana MA, Siddiqi SUH (1991). Sunflower seed yield as influenced by some agronomic and seed characters. Euphytica 56:137-142.

Annicchiarico P (2006). Diversity, genetic structure, distinctness and agronomical value of Italian lucerne (Medicago sativa L.) landraces. Euphytica 148:269-282.

Baye T, Becker HC (2005). Genetic variability and interrelationship of traits in the industrial oil crop Vernonia galamensis. Euphytica 142:119-129.

Board JE, Kang MS, Hartville BG (1997). Path analyses identify indirect selection criteria for yield of late planted soybean. Crop Sci 37:879-884.

Bridge J (2000). Nematodes of bananas and plantains in Africa:research trends and management strategies relating to the small-scale farmer. Acta Horticulturae 540:391-408.

Coors JG, Lowe CC, Murphy RP (1986). Selection for improved nutritional quality of alfalfa forage. Crop Sci 26:843-848.

Diz D A, Wofford DS, Schank SC (1994). Correlation and path-coefficient analyses of seed-yield components in pearl millet $\times$ elephant grass hybrids. Theoretical and Applied Genetics 89:112-115.

Fick GW, Holt DA, Lugg DG (1988). Environmental physiology and crop growth. Alfalfa and alfalfa improvement (Monograph 29). American Society of Agronomy Inc, Madison, Wisconsin, USA. 
Gil HC, Davis RL, Barnes RF (1967). Inheritance of in vitro digestibility and associated characters in Medicago sativa L. Crop Sci 7:19-21.

Gravois KA (1998). Optimizing selection for rough rice yield, head rice, and total milled rice. Euphytica 101:151-156.

Guler M, Adak MS, Ulukan H (2001). Determining relationships among yield and some yield components using path coefficient analysis in chickpea (Cicer arietinum L.). European Journal of Agronomy 14:161-166.

Hill Jr RR (1981). Selection for phosphorous and lignin content, 56 p. In: Report of the 27th Alfalfa Improvement Conf., Madison, WI. 8-10 July 1980. USDA, Peoria, IL.

Hill Jr RR, Barnes RF (1977). Genetic variability for chemical composition of alfalfa. II. Yield and traits associated with digestibility. Crop Sci 17:948-952.

Johnson JLS, Hansen JL, Viands DR (1994). Relationships between agronomic and quality traits in alfalfa as influenced by breeding. In: 34 North American Alfalfa Improvement Conferences, Ontario, Canada.

Julier B, Huyghe C, Ecalle C (2000). Within and among-cultivar genetic variation in alfalfa:Forage quality, morphology and yield. Crop Sci 40:365-369.

Kephart KD, Buxton DR, Hill Jr RR (1989). Morphology of alfalfa divergently selected for herbage lignin concentration. Crop Sci 29:778-782.

Kephart KD, Buxton DR, Hill Jr RR (1990). Digestibility and cell-wall components of alfalfa following selection for divergent herbage lignin concentration. Crop Sci 30:207212.

Kirilov A (2001). Lucerne quality and possibilities for its estimation. Proc. of the XIV Eucarpia Medicago spp. Group Meeting, Zargoza, Spain, 231-234 p.

Kozak M, Kang MS (2006). Note on modern path analysis in application to crop science. Communications in Biometry and Crop Science 1:32-34.

Lemaire G, Genier G, Lila M (1994). Growth dynamics and digestibility for two genotypes of lucerne having different morphology, 75-77 p. In: Management and Breeding of Perennial Lucerne for Diversified Purposes, Roma Italy.

Mohammadi SA, Prasanna BM, Singh NN (2003). Sequential path model for determining interrelationships among grain yield and related characters in maize. Crop Sci 43:16901697.

Popovic S, Cupic T, Grljusic S, Tucak M (2006). Use of variability and path analysis in determining yield and quality of alfalfa. Proceedings of XXVI Meeting of the EUCARPIA Fodder Crops and amenity Grasses Section, Perugia, Italy, 95-99 p.
Prosperi JM, Ronfort J, Genier J (1999). Constraints to the introduction of Medics in French Mediterranean farming's system. Proceedings of XIII Eucarpia Medicago ssp. Group, Perugia,Italy, 154-161 p.

Rabiei B, Valizadeh M, Gharayazie B, Moghaddam M (2004). Evaluation of selection indices for improving rice grain shape. Field Crops Research 89:359-367.

Radovic J, Lugic Z, Sokolovic D, Delic D, Stanisavljevic R (2006). Genetic variability for seed yield and seed yield component in alfalfa. Proceedings of XXVI Meeting of the EUCARPIA Fodder Crops and amenity Grasses Section, Perugia, Italy, 121-123 p.

Rotili P, Gnocchi G, Scotti C, Kertikova D (2001). Breeding of the alfalfa plant morphology for quality. Proceedings of the XIV EUCARPIA Medicago spp. Group Meeting, 25-27 p.

SAS Institute (1998). INC SAS/STAT users' guide release 7.0, Cary, NC, USA.

Sengul S (2002). Yield components, morphology and forage quality of native alfalfa ecotypes, online Journal of Biological Science 2:494-498.

Sheaffer CC, Martin NP, Lamb JF, Cuomo GR, Jewett JG, Quering SR (2000). Leaf and stem properties of alfalfa entries. Agronmy Journal 92:733-739.

Singh BU, Padmaja PG, Seetharama N (2004). Stability of biochemical constituents and their relationships with resistance to shoot fly, Atherigona soccata (Rondani) in seedling sorghum. Euphytica 136:279-289.

Shenk JS, Elliott FC (1971). Plant compositional changes resulting from two cycles of directional selection for nutritive value in alfalfa. Crop Sci 11:521-524.

Shipley B (2002). Cause and Correlation in Biology. A User's Guide to Path Analysis, Structural Equations and Causal Inference. Cambridge, UK: Cambridge University Press.

Smith DL, Hamel C (2005). Crops yield, physiology and processes. (Trans.) Y. Imam, and M.G. Seghatoleslami. Shiraz University Press. Iran.

Sumberg JE, Murphy RP, Lowe CC (1983). Selection of fiber and protein concentration in a diverse alfalfa population. Crop Sci 23:11-14.

Tavoletti S, Capitani E, Pierangeli S (1999). Evaluation of alfalfa populations collected in the Marche region. Lucerne and Medics for the XXI Century, Proc. Of the XIII EUCARPIA Medicago spp. Group Meeting, Instituto di Miglioramento Genetico Vegetale, Perugia, Italy, 228-230 p.

Tuckak M, Popovic S, Cupic T, GrljusicS, BolaricS, KozumplikV (2008). Genetic diversity of alfalfa (Medicago spp.) estimated by molecular markers and morphological characters. Period Biol 110:243-249. 